\title{
Effects of calcium on the growth of the rat conceptus during organogenesis in vitro
}

\author{
S. K. L. Ellington \\ Physiological Laboratory, University of Cambridge, Downing Street, Cambridge CB2 3EG, U.K.
}

\begin{abstract}
Summary. Embryos explanted at $10 \frac{1}{2}$ days were cultured for $24 \mathrm{~h}$ with the visceral yolk sac intact and with the parietal yolk sac intact or opened. The culture medium was undiluted rat serum or rat serum diluted with an equal volume of Hanks balanced saline solution. The calcium concentration of the medium was modified by the addition of calcium chloride. Optimum growth was achieved when the explants, with or without the parietal yolk sac intact, were cultured in medium containing $0.5-2.0 \mathrm{~mm}$ added calcium.

The calcium concentration was shown to affect the proliferation of trophoblast cells in the ectoplacental cone, the number of the trophoblastic giant cells in the parietal yolk sac and the expansion of the parietal yolk sac.

Histochemical tests on the decidua and embryonic tissue demonstrated high concentrations of calcium around the ectoplacental cone of $10 \frac{1}{2}$ day rat embryos in vivo.
\end{abstract}

\section{Introduction}

Culture techniques have now been established which support the growth and differentiation of rat embryos throughout the major part of organogenesis if the parietal yolk sac is opened at the start of the culture period (New, 1978). However, if the parietal yolk sac is left intact around the rest of the conceptus, embryonic growth is retarded and the development of both the parietal yolk sac and the ectoplacental cone is abnormal (Jolly \& Lieure, 1938; Payne \& Deuchar, 1972; Ellington \& New, 1980).

Ellington \& New (1980) compared the development of conceptuses (embryos with intact parietal yolk sacs) after culture in undiluted rat serum or in a 1:1 mixture of serum and Hanks balanced saline solution (HBSS). The parietal yolk sacs expanded more and the trophoblast cell morphology resembled that seen in vivo more closely in the conceptuses cultured in the diluted serum than in those cultured in undiluted rat serum. The culture medium was thus shown to influence the development of the parietal yolk sac but it was not known why the mixture of serum and HBSS should have this effect.

In a series of preliminary experiments to determine whether conceptus growth could be influenced by specific components in the culture medium it was demonstrated that the concentration of calcium ions in the medium influenced the growth of the conceptus (unpublished). The present experiments were designed to investigate the effect of the concentration of calcium ions in the medium on the expansion of Reichert's membrane, the morphology of the ectoplacental cone and the trophoblast cells and the growth of the embryo. The results of histochemical tests for the localization of calcium in the decidua are also described. 


\section{Materials and Methods}

Animals and cultures. All embryos and serum were obtained from CFHB rats (Hacking and Churchill, Huntingdon, U.K.). Female rats were left with males overnight and those with spermatozoa in the vagina the following morning were regarded as 0.5 days pregnant.

At about mid-morning $10 \frac{1}{2}$-day rats were lightly anaesthetized in ether vapour and then killed by cervical dislocation. Their abdominal cavities were opened and the gravid uteri removed and put into HBSS at $38^{\circ} \mathrm{C}$. All subsequent dissection was performed in dishes resting on a hollow Perspex platform which was warmed by circulating water at $38^{\circ} \mathrm{C}$. The uteri were opened and the decidual tissue dissected away from the embryonic membranes. In Exps 1-3, the parietal yolk sac was left intact around the remaining part of the explant (embryo and embryonic membranes). In Exp. 4, the parietal yolk sac was opened leaving the visceral yolk sac in direct contact with the culture medium. The maximum and minimum diameter of each explant was measured and recorded and the explants were then transferred to $60 \mathrm{ml}$ bottles containing the culture medium. The bottles were gassed with the appropriate gas mixture and placed on rollers in an incubator at $38^{\circ} \mathrm{C}$ ( New, Coppola \& Terry, 1973). All explants were in culture bottles within $45 \mathrm{~min}$ of the death of the mother. The explants from one mother were always divided between 2 or 3 different experimental procedures to reduce the possibility of genetic variations or slight differences in the time of mating affecting the experimental results.

The culture method used was based on that described by Ellington \& New (1980) for the optimum growth of the parietal yolk sac in vitro. Serum, prepared by the method of Steele (1972), was diluted to $50 \%$ with HBSS.

The concentration of calcium in the culture medium ( $1 \mathrm{ml} / \mathrm{explant})$ was varied by the addition of different quantities of calcium chloride to the HBSS. Standard $\mathrm{HBSS}$ contains $0 \cdot 14 \mathrm{~g} \mathrm{CaCl}_{2}$, i.e. $\sim 1 \mathrm{mM}-\mathrm{CaCl}_{2}$ (Paul, 1975). In an initial series of experiments, HBSS was prepared with various quantities of $\mathrm{CaCl}_{2}$ and without correction for osmolarity changes. In subsequent experiments the osmolarity of the solution was maintained at a constant level by adjusting the $\mathrm{NaCl}$ content. The changes in $\mathrm{NaCl}$ were always small compared to the total $\mathrm{NaCl}(8 \mathrm{~g} /$ litre in standard $\mathrm{HBSS})$. Both series of experiments yielded similar results. In Exps 1, 2 and 4 the osmolarity was maintained at a constant value by slight adjustments to the $\mathrm{NaCl}$ content. Throughout this paper the concentrations of added $\mathrm{CaCl}_{2}$ are quoted as the value in the culture medium (i.e. excluding any calcium already in the serum). In Exp. 3 in which the serum was not diluted, the $\mathrm{CaCl}_{2}$ was added directly to the serum and the osmolarity was not readjusted.

Having demonstrated that calcium in the culture medium can influence the development of the conceptus in vitro, cultures from Exps 2, 3 and 4 were repeated and the total calcium in the culture medium at the start and termination of the culture was assayed using a commercial kit (No. 585, Sigma, St Louis, Missouri, U.S.A.) for quantitative colorimetric determination of calcium in serum or plasma.

Cultures were gassed with a gas mixture containing oxygen, nitrogen and $5 \%$ carbon dioxide. At the start of each culture the gas phase contained $20 \%$ oxygen, after $8 \mathrm{~h}$ this was replaced by $40 \%$ oxygen and after $16 \mathrm{~h}$ by $95 \%$ oxygen.

Cultures were terminated after $24 \mathrm{~h}$ and all explants were examined for heart beat and blood circulation in the visceral yolk sac. The maximum and minimum diameters of the parietal yolk sac were measured and its surface area was calculated as the surface area of a sphere of diameter equal to the mean of the two measurements (at $10 \frac{1}{2}-11 \frac{1}{2}$ days the yolk sacs are approximately spherical).

The explants were then either processed for histological examination (see below) or the yolk sacs were opened and the embryonic development assessed. Embryos were examined, the somite number counted and the protein content of each embryo determined by the colorimetric method of Lowry, Rosebrough, Farr \& Randall (1951).

Histology. For routine examination after culture the explants were fixed in alcoholic Bouin's solution for at least 2 days, dehydrated, cleared and embedded in paraffin wax in the usual manner. Sections were cut at $5 \mu \mathrm{m}$ and stained in haematoxylin and eosin. 
To compare the rates of cell division in explants, $0 \cdot 1 \%$ colchicine was added to the culture medium $2 \mathrm{~h}$ before the end of some cultures. The explants were then fixed in Bouin's fluid, processed for light microscopy as usual, and sectioned perpendicular to the ectoplacental cone (and parallel to the allantoic stalk). Sections were cut at $5 \mu \mathrm{m}$ and every 10 th section was examined. All sections examined contained allantoic mesoderm and the middle ones of each series analysed included the junction of the allantoic stalk and the ectoplacental cone. The following observations were made from each section: (a) number of mitotic figures in allantoic mesoderm, (b) number of mitotic figures and cells in the trophoblast layer of the ectoplacental cone, (c) percentage of Reichert's membrane covered by giant cells, and (d) number of giant cells (giant cell nuclei) in the parietal yolk sac. The mitotic indices for the allantoic mesoderm and the trophoblast layer of the ectoplacental cone were calculated as the ratio of dividing to non-dividing cells $\times 100$.

To prepare tissue for the histochemical tests for the localization of calcium, decidual swellings from $10 \frac{1}{2}$-day rats were fixed in neutral formalin for 2-4 days. They were then dehydrated, cleared, embedded in paraffin wax and sectioned at $5 \mu \mathrm{m}$. Three histochemical tests were used, chloranilic acid in $96 \%$ alcohol (cited in Disbrey \& Rack, 1970), chloranilic acid in aqueous solution (Carr, Ramo \& Feichtmeir, 1961) and a modification of the von Kossa method (Disbrey \& Rack, 1970). Other decidual swellings were fixed in $1 \%$ osmium tetroxide containing $5 \%$ potassium pyronantimonate (pH 8.5); controls were processed in the same fixative to which 10 mM EGTA were added (Simson \& Spicer, 1975).

Statistical analyses. In each experiment the results from all the treatments were analysed by the Kruskal-Wallis one-way analysis of variance to test the null hypothesis that the calcium concentration in the culture media was irrelevant. The results from different culture conditions were then compared by Student's $t$ test. In each experiment the results from all samples were compared, but only those with significant differences are noted in the tables.

\section{Results}

Experiment 1: culture of explants with intact parietal yolk sacs in diluted serum containing a wide range of calcium concentrations

Calcium concentrations over a wide range were tested to demonstrate whether the calcium concentration did affect growth in vitro and to establish a useful range for subsequent experiments.

The surface area of the parietal yolk sac increased most during culture in medium containing 0.5

Table 1. The culture of rat embryo explants with intact parietal yolk sacs (PYS) in diluted serum containing a wide range of calcium concentrations

\begin{tabular}{|c|c|c|c|c|c|}
\hline \multirow[b]{3}{*}{$\begin{array}{c}\text { Added } \\
\mathrm{Ca}^{2+}(\mathrm{mM})\end{array}$} & \multirow[b]{3}{*}{$\begin{array}{c}\text { No. of } \\
\text { embryos }\end{array}$} & \multirow{3}{*}{$\begin{array}{c}\text { Start of culture } \\
\text { Surface } \\
\text { area of PYS } \\
\left(\mathrm{mm}^{2}\right)\end{array}$} & \multicolumn{3}{|c|}{ End of culture } \\
\hline & & & \multirow{2}{*}{$\begin{array}{c}\text { Surface } \\
\text { area of PYS } \\
\left(\mathrm{mm}^{2}\right) \\
(\% \text { increase })\end{array}$} & \multicolumn{2}{|c|}{ No. of embryos with: } \\
\hline & & & & Heart beat & $\begin{array}{l}\text { Yolk sac } \\
\text { circulation }\end{array}$ \\
\hline EGTA & 12 & $23 \cdot 4 \pm 0.5$ & $15.9 \pm 2.7(-32)$ & 1 & 0 \\
\hline 0.5 & 12 & $24.2 \pm 0.9$ & $* 29.4 \pm 1.7(21)$ & 12 & 4 \\
\hline $5 \cdot 0$ & 12 & $22.8 \pm 0.7$ & $* 26.5 \pm 1.6(16)$ & 11 & 1 \\
\hline $10 \cdot 0$ & 12 & $25.3 \pm 0.7$ & ${ }^{*} 25.2 \pm 1.3(0)$ & 3 & 0 \\
\hline $20 \cdot 0$ & 12 & $23.4 \pm 0.6$ & $17.5 \pm 1.6(-25)$ & 0 & 0 \\
\hline Kruskal-Wa & & N.S. & $P<0.001$ & & \\
\hline
\end{tabular}

Values are mean \pm s.e.m.

* Significantly different from values for explants cultured in medium with EGTA or $20 \cdot 0$ mM-added calcium, $P<0.01$. 
or $5.0 \mathrm{~mm}$ added calcium. Explants cultured in medium with no added calcium and $5 \mathrm{mM}$-EGTA or in medium containing $20 \mathrm{~mm}$ added calcium did not grow in culture, indeed they became considerably smaller (Table 1). (In subsequent experiments EGTA was omitted from the culture medium to eliminate the possibility of it having a toxic effect on the conceptus.)

The calcium concentration not only affected the overall growth of the explant but also had a marked effect on the morphology and proliferation of the trophoblast cells. After culture in medium containing EGTA, the explants contained no trophoblast cells; the ectoplacental cone remained as a spherical mass of allantoic mesoderm and the parietal yolk sac consisted only of parietal endoderm cells and Reichert's membrane (PI. 1, Fig. 1).

Explants cultured in medium containing $0.5 \mathrm{~mm}$ added calcium or no added calcium (and no EGTA) had a thin layer of elongated giant cells covering most of the outer surface of Reichert's membrane. The allantoic mesoderm of the ectoplacental cone was well vascularized with embryonic blood and contained few dividing cells. The trophoblast layer of the ectoplacental cone was thin with little mitotic activity (Pl. 1, Fig. 2; Table 2).

By contrast, explants cultured in medium containing higher concentrations of calcium tended to have fewer giant cells in the parietal yolk sac. These cells were rounded and formed a thick cellular layer near the ectoplacental cone region, but rarely covered more than two-thirds of the surface of Reichert's membrane. The allantoic mesoderm was bounded by a thick layer of trophoblast cells which, after colchicine treatment could be seen to have contained proliferating cells (Pl. 1, Figs 3 \& 4; Table 2).

Experiment 2: culture of explants with intact parietal yolk sacs in diluted serum containing a narrow range of calcium concentrations

The explants showed the greatest increase in surface area when cultured in medium with 0.5 or $1.0 \mathrm{~mm}$ added calcium. The embryos cultured in medium with $1.0 \mathrm{~mm}$-calcium had the greatest number of somites (Table 3a). No morphological differences in the parietal yolk sacs and the ectoplacental cones from the different culture media were detectable.

\section{PLATE 1}

Fig. 1. A rat embryo explant after $24 \mathrm{~h}$ in calcium-free medium. There are no remaining trophoblast cells in the ectoplacental cone (EC) or in the parietal yolk sac (PY).

Fig. 2. An explant after $24 \mathrm{~h}$ culture in medium with $0.5 \mathrm{~mm}$-added calcium. The allantoic mesoderm (AM) is well vascularized and is surrounded by a thin layer of trophoblast cells (T). Elongated giant cells $(G)$ form the outer layer of the parietal yolk sac.

Fig. 3. An explant after $24 \mathrm{~h}$ culture in medium containing $10 \mathrm{~mm}$-added calcium. The allantoic mesoderm (AM) is surrounded by a thick layer of trophoblast cells $(T)$. The giant cells $(G)$ in the parietal yolk sac are rounded and closely packed.

Fig. 4. An explant after $24 \mathrm{~h}$ in culture in medium containing $20 \mathrm{~mm}$-added calcium. The allantoic mesoderm (AM) is surrounded by a thick layer of trophoblast cells (T). A thin layer of rounded giant cells $(\mathrm{G})$ covers part of the surface of Reichert's membrane.

\section{PLATE 2}

Fig. 5. Calcium deposits (C) in the decidual tissue (D) around the ectoplacental cone (EC) of a $10 \frac{1}{2}$-day rat embryo. EEC, extra-embryonic coelom; VYS, visceral yolk sac. The section was stained with light green, incubated in aqueous chloranilic acid and photographed under brightfield illumination.

Fig. 6. The same field as in Fig. 5 photographed under polarized light to show the birefringent crystals which are precipitated by the reaction between chloranilic acid and calcium. 
Table 2. Analysis of rat embryo explants cultured in medium containing $0 \cdot 1 \%$ colchicine for the final $2 \mathrm{~h}$ of the 24-h culture period in dilute serum containing a wide range of calcium concentrations

\begin{tabular}{|c|c|c|c|c|}
\hline \multirow{2}{*}{$\begin{array}{c}\text { Added } \\
\mathrm{Ca}^{2+}(\mathrm{mM})\end{array}$} & \multirow{2}{*}{$\begin{array}{c}\text { No. of } \\
\text { explants } \\
\text { analysed (no. } \\
\text { of sections) }\end{array}$} & \multirow{2}{*}{$\begin{array}{l}\text { No. of giant } \\
\text { cell nuclei per } \\
\text { section in the } \\
\text { parietal yolk sac }\end{array}$} & \multicolumn{2}{|c|}{ Mitotic indices of cells in the ectoplacental cone } \\
\hline & & & Allantoic mesoderm & Trophoblast \\
\hline 0 & $4(40)$ & $78 \pm 6$ & $0.36 \pm 0.04$ & $0.06 \pm 0.02$ \\
\hline 0.5 & $4(40)$ & $70 \pm 9$ & $0.58 \pm 0.02$ & $0 \cdot 12 \pm 0.04$ \\
\hline $5 \cdot 0$ & $4(40)$ & $64 \pm 5$ & $0.85 \pm 0.26$ & $* 0.35 \pm 0.05$ \\
\hline $10 \cdot 0$ & $4(40)$ & $57 \pm 11$ & $0.54 \pm 0.02$ & $0.40 \pm 0.12$ \\
\hline $20 \cdot 0$ & $4(40)$ & $* 56 \pm 3$ & $0 \cdot 34 \pm 0 \cdot 10$ & $0.29 \pm 0.12$ \\
\hline \multicolumn{2}{|c|}{ Kruskal-Wallis test } & $P<0.001$ & $P<0.001$ & $P<0.001$ \\
\hline
\end{tabular}

Values are mean \pm s.e.m.

* Significantly different from values for explants cultured in medium with no added calcium, $P<0.01$.

\section{Experiment 3: culture of explants with intact parietal yolk sacs in undiluted serum containing a narrow range of calcium concentrations}

The greatest increase in surface area of the explants occurred in serum with 1.0 or $2.0 \mathrm{~mm}$ added calcium. The higher calcium concentrations also supported better development of the embryos. The embryos from cultures with 1.0 or $2.0 \mathrm{~mm}$ added calcium had higher somite numbers and contained more protein than did those cultured in serum with no added calcium (Table $3 \mathrm{~b}$ ). As in Exp. 2, no consistent morphological differences between explants from the different experimental conditions could be detected.

Table 3. The culture of rat embryo explants with intact parietal yolk sacs (PYS) in (a) diluted serum and (b) undiluted serum containing a narrow range of calcium concentrations

\begin{tabular}{|c|c|c|c|c|c|c|}
\hline \multirow[b]{2}{*}{$\begin{array}{c}\text { Added } \\
\mathrm{Ca}^{2+}(\mathrm{mM})\end{array}$} & \multirow[b]{2}{*}{$\begin{array}{l}\text { No. of } \\
\text { embryos }\end{array}$} & \multirow{2}{*}{$\begin{array}{l}\text { Start of culture } \\
\text { Surface area } \\
\text { of PYS }\left(\mathrm{mm}^{2}\right)\end{array}$} & \multicolumn{4}{|c|}{ End of culture } \\
\hline & & & $\begin{array}{c}\text { Surface } \\
\text { area of PYS } \\
\text { (\% increase) }\end{array}$ & $\begin{array}{l}\text { No. of } \\
\text { embryos with } \\
\text { heart beat }\end{array}$ & $\begin{array}{l}\text { Somite } \\
\text { no. }\end{array}$ & $\begin{array}{c}\text { Protein } \\
\text { content }(\mu \mathrm{g})\end{array}$ \\
\hline \multicolumn{7}{|c|}{ (a) Diluted serum } \\
\hline 0 & 20 & $23 \cdot 0 \pm 0 \cdot 3$ & $27 \cdot 7 \pm 1 \cdot 1(21)$ & 12 & $21 \cdot 1 \pm 1 \cdot 0$ & $95 \cdot 2 \pm 5 \cdot 3$ \\
\hline 0.25 & 20 & $22.9 \pm 0.4$ & $30 \cdot 2 \pm 1 \cdot 1(32)$ & 9 & $19 \cdot 0 \pm 1 \cdot 1$ & $87.3 \pm 5.7$ \\
\hline 0.50 & 20 & $24 \cdot 1 \pm 0.4$ & $* 34.1 \pm 0.9(41)$ & 19 & $22.6 \pm 0.8$ & $107.8 \pm 6.2$ \\
\hline 1.0 & 20 & $23 \cdot 1 \pm 0 \cdot 4$ & $* 34.8 \pm 0.9(50)$ & 18 & $\uparrow 23.5 \pm 0.6$ & $\dagger 95.9 \pm 5.3$ \\
\hline $2 \cdot 0$ & 20 & $23.9 \pm 0.3$ & $30.1 \pm 0.8(26)$ & 19 & $21.9 \pm 0.9$ & $104 \cdot 1 \pm 7 \cdot 6$ \\
\hline \multicolumn{2}{|c|}{ Kruskal-Wallis test } & N.S. & $P<0.001$ & & N.S. & $P<0.001$ \\
\hline \multicolumn{7}{|c|}{ (b) Undiluted serum } \\
\hline 0 & 20 & $22 \cdot 2 \pm 0.5$ & $28 \cdot 3 \pm 1 \cdot 1(27)$ & 18 & $21.9 \pm 0.8$ & $108 \pm 4.7$ \\
\hline 0.25 & 20 & $23.5 \pm 0.7$ & $31 \cdot 3 \pm 1 \cdot 3(33)$ & 16 & $22.8 \pm 0.8$ & $111 \pm 5 \cdot 7$ \\
\hline 0.50 & 20 & $23 \cdot 3 \pm 0.5$ & $30 \cdot 6 \pm 1 \cdot 4(31)$ & 15 & $22.8 \pm 1.0$ & $123 \pm 7 \cdot 2$ \\
\hline $1 \cdot 0$ & 20 & $23.5 \pm 0.5$ & $* 33.8 \pm 1.4(44)$ & 19 & $25.0 \pm 0.4$ & $*+135 \pm 6.4$ \\
\hline $2 \cdot 0$ & 20 & $24.5 \pm 0.5$ & ${ }^{* *} 34.9 \pm 1.0(42)$ & 18 & $22 \cdot 3 \pm 1 \cdot 0$ & ${ }^{*} 135 \pm 7.8$ \\
\hline \multicolumn{2}{|c|}{ Kruskal-Wallis test } & N.S. & $P<0.01$ & & $P<0.05$ & $P<0.01$ \\
\hline
\end{tabular}

Values are mean \pm s.e.m.

(a) * Significantly different from values for explants cultured in medium with $0,0.25$ or 2 mm-added calcium, $P<$ 0.01 .

† Significantly different from values for explants cultured in medium with $0.25 \mathrm{~mm}$-added calcium, $P<0.01$.

(b) Significantly different from the values for explants cultured with no added calcium, ${ }^{*} P<0.01,{ }^{* *} P<0.001$.

+ Significantly different from the values for explants with $0.25 \mathrm{~mm}$-added calcium, $P<0.001$. 
Experiment 4: culture of explants with opened parietal yolk sacs in diluted serum containing a narrow range of calcium concentrations

Embryos cultured in medium with $0.5,1.0$ or $2.0 \mathrm{~mm}$ added calcium had more somites and higher protein contents than did embryos cultured in medium with no added calcium or $0.25 \mathrm{~mm}$ added calcium (Table 4).

Table 4. The culture of rat embryo explants with opened parietal yolk sacs in diluted serum containing a narrow range of calcium concentrations

\begin{tabular}{|c|c|c|c|c|c|}
\hline \multirow[b]{2}{*}{$\begin{array}{c}\text { Added } \\
\mathrm{Ca}^{2+}(\mathrm{mm})\end{array}$} & \multirow[b]{2}{*}{$\begin{array}{l}\text { No. of } \\
\text { embryos }\end{array}$} & \multicolumn{2}{|c|}{ No. of embryos with: } & \multirow[b]{2}{*}{ Somite no. } & \multirow[b]{2}{*}{$\begin{array}{c}\text { Protein } \\
\text { content }(\mu \mathrm{g})\end{array}$} \\
\hline & & $\begin{array}{c}\text { Heart } \\
\text { beat }\end{array}$ & $\begin{array}{c}\text { Yolk sac } \\
\text { circulation }\end{array}$ & & \\
\hline 0 & 20 & 18 & 15 & $26 \cdot 6 \pm 0 \cdot 3$ & $293 \pm 13$ \\
\hline 0.25 & 20 & 18 & 13 & $26.4+0.3$ & $284 \pm 10$ \\
\hline 0.5 & 20 & 20 & 17 & $*+27.9 \pm 0.3$ & $*+346 \pm 12$ \\
\hline $1 \cdot 0$ & 20 & 19 & 17 & $* *+28.2 \pm 0.2$ & $+338 \pm 10$ \\
\hline $2 \cdot 0$ & 20 & 20 & 20 & $+27.9 \pm 0.3$ & ${ }^{*}+349 \pm 12$ \\
\hline \multicolumn{4}{|c|}{ Kruskal-Wallis test } & $P<0.001$ & $P<0.001$ \\
\hline
\end{tabular}

Values are mean \pm s.e.m.

Significantly different from values for explants cultured with no added calcium, ${ }^{*} P<0 \cdot 01,{ }^{*} P$ $<0 \cdot 001$.

$\dagger$ Significantly different from the values for explants cultured with 0.25 mm-added calcium, $P<$ $0 \cdot 001$.

\section{Calcium assays}

Calcium concentrations in undiluted serum before culture were $2.3 \pm 0.1 \mathrm{~mm}$. Changes in the concentration of calcium in the medium during culture were always relatively small. Explants cultured in media containing $\leqslant 2.0 \mathrm{~mm}$ total calcium tended to show a small net efflux of calcium into the culture medium during the $24-\mathrm{h}$ cultures (mean increase in calcium concentration in the medium: $0.07 \pm 0.01 \mathrm{mM}, n=10$ ). By contrast, explants cultured in media containing concentrations of total calcium $>2.0 \mathrm{~mm}$ tended to have a net influx of calcium (mean decrease in calcium concentration in the medium: $0.25 \pm 0.1 \mathrm{mM}, n=10$ ). The changes in the calcium concentrations of media initially containing $\leqslant 2 \mathrm{~mm}$-calcium and in media initially containing $>2$ mM-calcium were significantly different $(P<0.01, t$ test). These calcium fluxes appeared not to be influenced by the presence of an intact parietal yolk sac.

\section{Histochemistry}

Each of the histochemical tests showed a higher level of calcium around the ectoplacental cone than in any other region of the decidua or embryonic tissue (Pl. 2, Figs 5 \& 6).

\section{Discussion}

The work described in this paper demonstrates that calcium levels in the culture medium can influence the expansion of the parietal yolk sac, the proliferation and morphology of the trophoblast cells and the growth of the embryo. It is possible that in vivo the calcium deposits around the ectoplacental cone could be acting as an exchangeable pool of calcium to buffer the conceptus against fluctuations in the maternal blood calcium levels which could be detrimental to embryonic development. The mechanism by which the calcium concentration of medium influences the expansion of the parietal yolk sac is uncertain. Although it has been demonstrated that the 
trophoblast cells are modified by specific culture conditions all available evidence suggests that these cells do not influence the secretion or expansion of Reichert's membrane.

During the culture of isolated sheets of parietal yolk sac the parietal endoderm cells continued to secrete Reichert's membrane both in the presence and absence of giant cells (Minor, Hoch, Koszalka, Brent \& Kefalides, 1976). In the experiments described in this papet the expansion of the parietal yolk sac enveloping each conceptus appeared to be independent of the presence of giant cells. All conceptuses were approximately spherical after culture, regardless of the extent to which they were covered by giant cells, i.e. the uncovered Reichert's membrane apparently expanded at the same rate as that covered by giant cells. The calcium concentrations could be modifying the expansion of the parietal yolk sac by influencing the growth of the other components of the explants so varying the pressure exerted on Reichert's membrane. Experiment 4 demonstrated that explants with opened parietal yolk sacs did grow better in the higher calcium concentrations. Calcium could also be affecting the molecular structure of Reichert's membrane so as to modify the pliability or permeability of the membrane. There is no current evidence to support or refute this possibility.

It has been shown previously that the parietal yolk sac expands more when explants are cultured in serum diluted with an equal volume of HBSS than when they are cultured in undiluted serum. To ascertain whether the improved expansion was simply a result of the presence of the free calcium contained in the HBSS, embryos were cultured in undiluted serum with added calcium. Even at optimum calcium levels the expansion of the parietal yolk sac in undiluted serum, like that in diluted serum, was only about half that which occurs during a similar period in vivo (unpublished). In all the other experimental conditions tested the expansion of the parietal yolk sac was less than that which occurs in vivo during an equivalent period (Ellington \& New, 1980; S. K. L. Ellington, unpublished). The reason for this is not known. In culture, Reichert's membrane tends to thicken abnormally and the parietal endoderm cells, which continue to divide, become abnormally closely packed. Both these factors could contribute to a decreased permeability of the parietal yolk sac, and hence a decrease in the exchange across the visceral yolk sac which could be detrimental to embryonic growth (embryonic growth in vitro is considerably retarded in the presence of an intact parietal yolk sac, see Tables $3 \mathrm{a} \& 4$ ). It is also possible that, in vivo, the decidua could be contributing some factor essential to the normal expansion of the parietal yolk sac which is either absent or insufficiently concentrated in serum.

The 'optimum' total calcium concentration for rat conceptus culture appears to be higher in undiluted serum $(2 \cdot 3 \pm 1 \mathrm{~mm})$ than in diluted serum $(1 \cdot 15 \pm 1 \mathrm{~mm})$ (see Tables $3 \mathrm{a} \& 3 \mathrm{~b})$. This difference may reflect differences in the proportions of free and bound calcium in each; dilution of the serum reduces the concentration of calcium-binding proteins.

The changes in the concentration of calcium in the culture medium were small compared to those recorded by Sanyal (1980) who demonstrated a $25 \%$ increase in the calcium concentration of the media after culturing $10 \frac{1}{2}$-day explants for $48 \mathrm{~h}$. The differences in the two sets of observations could be a result of the difference in the age of the embryos at the termination of the culture or in the length of the culture. Sanyal (1980) reported that after $48 \mathrm{~h}$ in culture only $40 \%$ of explants had beating hearts, and presumably fewer had blood circulation in the visceral yolk sac. Lack of blood circulation could profoundly affect normal mechanisms of transport across the visceral yolk sac.

There have been numerous studies of factors influencing the development of the trophoblast cells. It has been shown that inductive effects of other tissues within the conceptus (Gardner, 1972) and the tissue integrity of the trophoblast cells (Ilgren, 1981) are important factors in the normal development of the trophoblastic tissue. The culture of intact conceptuses probably eliminates the above two variables and could possibly be another useful tool for the further study of trophoblast differentiation and development in the post-implantation embryo.

I thank Dr D. A. T. New for helpful discussion especially during the preparation for this manuscript; Miss P. A. Blundell for technical assistance; and the Medical Research Council for financial support. 


\section{References}

Carr, L.B., Ramo, O.M. \& Feichtmeir, T.V. (1961) A method of demonstrating calcium in tissue sections using chloranilic acid. J. Histochem. Cytochem. 9, $415-417$.

Disbrey, B.D. \& Rack, J.H. (1970) Histological Laboratory Methods. E. \& S. Livingstone, Edinburgh.

Ellington, S.K.L. \& New, D.A.T. (1980) In-vitro development of the rat parietal yolk sac. $J$. Reprod. Fert. 60, 377-382.

Gardner, R.L. (1972) An investigation of inner cell mass and trophoblastic tissue following their isolation from the mouse. J. Embryol. exp. Morph. 28, 279-312.

Ilgren, E.B. (1981) On the control of the trophoblastic giant-cell transformation in the mouse: homotypic cellular interactions and polyploidy. J. Embryol. exp. Morph. 62, 183-202.

Jolly, J. \& Lieure, C. (1938) Recherches sur la culture des oeufs des mammifères. Archs Anat. microsc. 34, 307374.

Lowry, O.H., Rosebrough, N.J., Farr, A.L. \& Randall, R.J. (1951) Protein measurement with the Folin phenol reagent. J. biol. Chem. 193, 265-275.

Minor, R.R., Hoch, P.S., Koszalka, T.R., Brent, R.L. \& Kefalides, N.A. (1976) Organ cultures of the embryonic rat parietal yolk sac. 1. Morphological and autoradiographic studies of the deposition of the collagen and noncollagen glycoprotein components of basement membrane. Devl Biol. 48, 344-364.

New, D.A.T. (1978) Whole-embryo culture and the study of mammalian embryos during organogenesis. Biol. Rev. 53, 81-122.

New, D.A.T., Coppola, P.T. \& Terry, S. (1973) Culture of explanted rat embryos in rotating tubes. $J$. Reprod. Fert. 35, 135-138.

Paul, J. (1975) Cell and Tissue Culture, 5th edn. Churchill Livingstone, Edinburgh.

Payne, G.S. \& Deuchar, E.M. (1972) An in vitro study of functions of embryonic membranes in the rat. $J$. Embryol. exp. Morph. 27, 533-542.

Sanyal, M.K. (1980) Development of the rat conceptus in vitro and associated changes in components of culture medium. J. Embryol. exp. Morph. 58, 1-12.

Simson, J.A.V. \& Spicer, S.S. (1975) Selective subcellular localization of cations with variants of petassium (pryo) antimonate technique. J. Histochem. Cytochem. 23, 575-598.

Steele, C.E. (1972) Improved development of "rat eggcylinders" in vitro as a result of fusion of the heart primordia. Nature, Lond. 237, 150-151.

Received 1 July 1982 